\title{
The Circulation of the École romande du droit naturel in Eighteenth-Century Italy
}

\author{
Elisabetta Fiocchi Malaspina
}

This chapter investigates how some of the key texts of the so called école romande du droit naturel were translated, received and used in the Italian context during the long eighteenth century. ${ }^{1}$ The circulation of Emer de Vattel's treatise on the law of nations, Le droit des gens (1758), will be considered together with Jean Barbeyrac's translations of Pufendorf's writings and with the various editions of Jean-Jacques Burlamaqui's works. ${ }^{2}$ The école romande had a great influence on the propagation of theories of natural law and law of

1 Alfred Dufour termed the natural law teaching and literary production in the French-speaking part of Switzerland école romande du droit naturel. Although identifying a 'school' within the natural law movement may appear problematic, Dufour held this term to be appropriate, in the sense of 'an intellectual movement committed to defend, in connection with one or several teachers, a certain number of principles, and to propagate them through speech or writing'. According to Dufour, the school was a kind of mediation between the German natural law theories (represented, among others, by Pufendorf, Thomasius and Wolff) and the French ones symbolised, for example, by the works of Montesquieu, Rousseau and Voltaire. See Alfred Dufour, Le mariage dans l'école allemande du droit naturel moderne au XVIIIe siècle (Paris: Libraire générale de droit et de jurisprudence, 1976), 12 (author's translation), and Alfred Dufour, 'Die Ecole romande du droit naturel - ihre deutschen Wurzeln,' in Humanismus und Naturrecht in Brandenburg-Preussen, ed. Hans Thieme (Berlin: W. de Gruyter, 1979), 133143. See also: Simone Zurbuchen, 'Das Prinzip des Naturrechts in der école romande du droit naturel,' Jahrbuch für Recht und Ethik 12 (2004): 189-211, and Simone Zurbuchen, 'Teaching the Law of Nature and Nations in the Swiss Context,' Etudes Lumières.Lausanne, 6 (novembre 2018), 1, accessed 15 February 2019, http://lumieres.unil.ch/fiches/biblio/9472/.

2 Besides the Principes du droit naturel (1747) and the Principes du droit politique (1751) I will also account for the new and annotated edition of Fortunato Bartolomeo de Felice, Principes du droit de la nature et des gens, 8 vols., Yverdon: [de Félice], 1766-1768. On de Felice see Stefano Ferrari, Fortunato Bartolomeo De Felice. Un intellettuale cosmopolita nell'Europa dei Lumi (Milano: Franco Angeli, 2017). On Barbeyrac as translator see: Giulia Maria Labriola, Barbeyrac interprete di Pufendorf e Grozio. Dalla costruzione della sovranità alla teoria della resistenza (Napoli: Editoriale Scientifica, 2003); Meri Päivärinne, 'Translating Grotius's De jure belli ac pacis: Courtin vs Barbeyrac,' Translation Studies 5, 1 (2012): 33-47. 
nations on the Italian peninsula, in a context that was marked by the presence of very different political regimes.

As is well known, the Peace of Utrecht in 1713, the Treaty of Rastatt in 1714 and the Hague Treaty of 1720 marked the end of Spanish rule in Italy. As a result of the Aachen Peace of 1748, the Italian peninsula was fragmented. In the north, Piedmont was ruled by the Savoy dynasty, Lombardy was under Austrian rule, the Duchy of Parma, Piacenza and Guastalla were under the control of the Bourbon family, while Venice remained independent and Florence governed by Francis II of Lorraine. In the south the Bourbons were on the throne in Naples with which Sicily was united in 1815 .

This peculiar situation constituted the context for enlightened debates on natural law, diplomacy and the law of nations. Discussions were often stimulated by texts that came from outside of Italy, and translations, in many cases supplemented with annotations, played an important role in arousing interest in topics such as social contract, sovereignty, constitutions, or the relationship between state and religion. The école romande du droit naturel had a major impact on these debates, as shown by Italian historians and legal historians who have investigated the significance of the Italian translations of Barbeyrac, Burlamaqui and Vattel. Antonio Trampus has pointed out, for example, that the Italian version of Vattel's Le droit des gens was considered a benchmark for a new political science. ${ }^{3}$ Indeed, Vattel's doctrines were discussed and variously adapted to different Italian contexts. ${ }^{4}$

3 Antonio Trampus, 'Il ruolo del traduttore nel tardo illuminismo: Lodovico Antonio Loschi e la versione italiana del Droit des gens di Emer de Vattel,' in Il linguaggio del tardo illuminismo. Politica, diritto e società civile, ed. Antonio Trampus (Roma: Edizioni di storia e letteratura, 2011), 81-108; A. Trampus, 'The circulation of Vattel's Droit des gens in Italy: the doctrinal and practical model of government,' in War, Trade and Neutrality. Europe and the Mediterranean in seventeenth and eighteenth centuries, ed. Antonella Alimento (Milano: FrancoAngeli 2011), 217-232; A. Trampus, 'La traduzione toscana del Droit des gens di Emer de Vattel (circa 1780): contesti politici, transferts culturali e scelte traduttive,' in Traduzione e Transferts nel XVIII secolo tra Francia, Italia e Germania, ed. Giulia Cantarutti, Stefano Ferrari (Milano: Franco Angeli, 2013), 153-174; A. Trampus, 'Le costituzioni italiane prime di Cadice: Vattel e le radici democratiche italiane,' in Cadice e oltre: costituzione, nazione e libertà. La carta gaditana nel bicentenario, ed. García Sanz et al. (Roma: Istituto per la Storia del Risorgimento italiano, 2015), 161-172; A. Trampus, 'Dalla libertà religiosa allo Stato nazione: Utrecht e le origini del sistema internazionale di Emer de Vattel,' in I trattati di Utrecht: una pace di dimensione europea, ed. Frédéric Ieva (Roma: Viella, 2016), 93-106.

4 See Elisabetta Fiocchi Malaspina, L'eterno ritorno del Droit des gens di Emer de Vattel (secc. XVIII-XIX). L'impatto sulla cultura giuridica in prospettiva globale (Frankfurt am Main: Global Perspectives on Legal History, Max Planck Institute for European Legal History Open Access Publication, 2017), http://dx.doi.org/10.12946/gplh8. 
In focusing on translation, transfer and reception, this chapter draws on recent methodological reflections in legal history which suggest that a purely sectoral approach to legal phenomena should be replaced by an interdisciplinary approach, the latter allowing an assessment of law as a dynamic phenomenon that needs to be put into context in terms of space and time. ${ }^{5}$ This manner of proceeding will reveal the political nature of translation, with its frequent conscious manipulations of text. Processes of translation will be presented in three areas of research, or scenarios, related to the propagation of natural law and the law of nations. The first scenario deals with the Italian translation of Barbeyrac's works, intended as a tool for mediating Protestant ideas in a Catholic context. The second focuses on the political contexts of the reception and translation of Burlamaqui's and Vattel's writings. In the third scenario, it will be examined how various works of the école romande were used in teaching the law of nature and nations in different academic contexts in Italy.

The first translation to be considered in this section is Giovambattista Almici's Il diritto della natura e delle genti o sia sistema generale de' principii li più importanti di morale, giurisprudenza, e politica (4 vols, 1757-1759), published in Venice by Pietro Valvasense. Almici was born in Brescia in 1717. He received his doctorate utroque jure in Padua in 1751, became assistant to the chief magistrate of Crema, then of Val Camonica. The cultural and social context in which he lived was that of Brescia Jansenism. ${ }^{6}$ His younger brother, Pietro Camillo, biblical scholar and theologian, entered the Congregation of the Oratory, and was one of the most important Italian critics of the Italian and foreign Enlightenment. ${ }^{7}$

5 See Thomas Duve, 'European Legal History - Global Perspectives Working Paper for the Colloquium European Normativity - Global Historical Perspectives' (Max Planck-Institute for European Legal History, September 2-4 2013), in Max Planck Institute for European Legal History Research Paper Series 6 (2013): 18, accessed 28 January 2017, http:// ssrn.com/ abstract $=2292666$.

6 Stefania Stoffella, 'Almici Giovambattista,' in Dizionario Biografico Giuristi Italiani (XII-XX secolo), ed. Italo Birocchi et al. (Bologna: Il Mulino, 2013), vol. I, 45.

7 Gianni Sofri, 'Pietro Camillo,' in Dizionario Biografico degli Italiani 2 (1960), 512. He wrote Osservazioni critiche sul libro intitolato Dei delitti e delle pene, under the pseudonym of Callimaco Mili, in which he strongly criticized the famous work of Cesare Beccaria, rejecting its contractualist premises and supporting the divine origin of sovereignty. See Callimaco Mili, 'Osservazioni critiche sul libro intitolato Dei delitti e delle pene,' Nuova raccolta d'opuscoli scientifici e filologici 13 (1765): II-XLVII. 
Almici's translation of Pufendorf's main work (De jure naturae et gentium) has been the subject of relevant Italian studies. ${ }^{8}$ Maurizio Bazzoli suggested that Almici might be seen as a sort of Italian Catholic Barbeyrac, because, after translating Pufendorf, he wanted to publish, in 1771, his richly annotated translation of Grotius's De jure belli ac pacis, but this never happened and it remained in manuscript form. ${ }^{9}$ Almici worked on the French translation of Pufendorf's text, obviously with the intention to revisit Barbeyrac's notes. In his view, a rectified and illustrated translation was necessary in order to disseminate in Italy, too, a work presenting natural law in a modern, scientific way, but without questioning the dictates of Catholicism. In fact, he wished to introduce his own version of Pufendorf in order to prevent any dissent from the Roman Church. He justified this manner of proceeding in the preface to the translation, where he also announced his intention to defend the positions of the Catholic Church on, for instance, lying, usury, matrimony, polygamy, pacts and duels. ${ }^{10}$ Despite this, Bazzoli concludes that Almici followed Barbeyrac 'more than it would appear, or, than he out of caution would admit."

Almici added a great number of notes to the translation. Interestingly, in volume IV, published in 1759, there are countless references to Vattel's Droit des gens, which had been published the previous year. In these notes Almici shows great appreciation for the thinking of the jurist from Neuchâtel, and on more than one occasion he does not hesitate to support him energetically, particularly on the issue of diplomacy. For example, in his commentary to Pufendorf's chapter on ambassadors, he refers to Vattel's now famous definition of the

8 Diego Panizza, 'La traduzione italiana del "De iure naturae" di Pufendorf: giusnaturalismo moderno e cultura cattolica nel Settecento,' Studi Veneziani 11 (1969): 483-528; Maurizio Bazzoli, 'Almici e la diffusione di Pufendorf nel Settecento Italiano,' Critica Storica 16 (1979): 3-10o; M. Bazzoli, 'Aspetti della recezione di Pufendorf nel Settecento italiano,' in Dal "De Jure Naturae et gentium" di Samuel Pufendorf alla codificazione prussiana del 1794. Atti del convegno internazionale, Padova, 25-26 ottobre 20o1, ed. Marta Ferronato (Padova: Cedam, 2005), 41-6o; Diego Quaglioni, 'Pufendorf in Italia. Appunti e notizie della prima diffusione della traduzione italiana del De iure naturae et gentium,' Il Pensiero Politico 32 (1999): 23-250; Stefania Stoffella, 'Assolutismo e diritto naturale in Italia nel Settecento,' Annali dell'Istituto storico italo-germanico, 26 (2000): 137-175; S. Stoffella, 'Il diritto di resistenza nel Settecento Italiano. Documenti per la storia della traduzione del De iure naturae et gentium di Pufendorf,' Magistrature et politique 2 (2001): 173-199, accessed 28 January 2017, http://laboratoireitalien.revues.org/261.

9 Bazzoli, Giambattista Almici e la diffusione di Pufendorf, 6.

$10 \quad$ Ibid., 18. See Giovambattista Almici, 'Prefazione,' in Pufendorf, Samuel, Il diritto della natura e delle genti o sia sistema generale de' principii li più importanti di morale, giurisprudenza e politica, rettificato, accresciuto e illustrato (Venezia: Pietro Valvasense, 1757), t. I, I.

11 Bazzoli, Giambattista Almici e la diffusione di Pufendorf, 22: 'le segue più di quanto non appaia, o per prudenza, non ammetta' (author's translation). 
'representative character' of ambassadors and the ensuing ranking of different kinds of ministers. ${ }^{12}$ Vattel's proposed division of roles was accepted in its entirety by Almici, who observes:

Nowadays various names and titles are given to these government Ministers, that I call Envoys, Residents, Ambassadors. The first two have not the character of personally representing their Prince, but they represent him only for such matters as they are sent to treat. By contrast, the Ambassadors have the character of representing their own Prince par excellence, personally, consequently they have greater dignity..$^{13}$

This example illustrates how Almici proceeded in order to present to his Italian readers an up-to-date version of the law of nature and nations: the wide use of notes allowed him to account for the most recent publications on various subjects.

Pufendorf's manual De officio hominis et civis, also translated into French by Barbeyrac (1707), had a unique history on the Italian peninsula. Two Italian translations were made of this work, one in Venice by Michele Grandi and one by Domenico Amati, published by Raymondi in Naples in 1780 and reissued in 1785. In the Neapolitan context, De officio was practically mandatory reading for generations of students during the age of reform. The same is true of Grotius's De jure belli ac pacis, which was translated into Italian by Antonio Porpora and published in Naples by De Dominicis in $1777 .{ }^{14}$

12 Emer de Vattel, The Law of Nations, Or, Principles of the Law of Nature, Applied to the Conduct and Affairs of Nations and Sovereigns, ed. Béla Kapossy, Richard Whatmore (Indianapolis, IN: Liberty Fund, 2008), book IV, chap. VI, §§ 70-74, 691-692.

13 'Al giorno d'oggi si danno vari nomi, e titoli a questi pubblici Ministri, cioè Inviati, Residenti, Ambasciatori. Li primi due non hanno il carattere di rappresentazione personale propriamente del Principe loro; ma lo presentano solo per quei tai affari, che trattare inviati sono; al contrario che gli Ambasciatori hanno il carattere rappresentativo del Proprio Principe per eccellenza, personale, onde di maggior dignità sono' (author's translation). Almici in Samuel Pufendorf, Il diritto della natura e delle genti o sia sistema generale de' principii li più importanti di morale, giurisprudenza e politica, rettificato, accresciuto e illustrato (Venezia: Pietro Valvasense 1759), vol. IV, book VIII, chap. X, § 1, 469, note 1 , also 472, 474, 479, in which Almici develops the character of the representativeness of ambassadors with reference to Vattel. For a full discussion on the ambassadors within the theories of the law of nations see Miloš Vec, 'L'ambassade dans la science du droit des gens,' in Les écrits relatifs à l'ambassadeur et à l'art de négocier du Moyen Âge au début du XIXe siècle, ed. Stefano Andretta, Stéphane Péquignot and Jean-Claude Waquet (Rome: École française de Rome, 2015), 487-522.

14 See: Vittorio Conti (ed.), La recezione di Grozio a Napoli nel Settecento (Firenze: Centro Editoriale Toscano, 2002). 
Grandi's translation comprised three quarto volumes, of which the first two were published in 1761 and the third in 1767 , all by Francesco Pitteri..$^{15}$ Grandi was spurred to attempt his translation 'having seen published in Italian the [...] Great Work of Pufendorf by Mr Giovanni Battista Almici'. Grandi publicly questioned Almici's method of directly modifying the text by making insertions and changes to it. He wished instead to recognize the right, or 'common desire', of readers to 'be able to read the opinions of these famous Authors expounded in the manner in which they were published.' ${ }^{16}$

Grandi's translation strategy was completely different from that of Almici. His intellectual bent, however, was very clear: although concerned about religious orthodoxy, he contributed to the circulation of Enlightenment ideas. As Bazzoli argues, Grandi made use of Pufendorf's fame to consciously diffuse among Italian readers Barbeyrac's interpretation of the law of nature and nations. He stoutly defended Barbeyrac against Almici's criticisms and, perhaps with the intention to further support the former's opinions, he followed Barbeyrac's own practice by adding two of the latter's essays in an appendix, which he also translated into Italian: the Discours sur la permission des loix (1715), and the Discours sur le bénéfice des loix (1716). ${ }^{17}$

\section{Second Scenario: Translation and Use of Burlamaqui's and Vattel's Works}

In the Grand Duchy of Tuscany, Burlamaqui's natural law theory was translated on the basis of de Felice's richly annotated edition Principes du droit de la nature et des gens (1766-1768). As Sandro Landi has shown, the translation was begun in Siena in 1772 for the publisher Bindi, but was swiftly halted by Stefano Bertolini, an official overseeing printing in Siena. ${ }^{18}$ Bertolini was convinced that Burlamaqui's text and de Felice's notes were potentially dangerous, mainly for their original theory about the foundation and the limits of royal power, and about the prerogatives of princes concerning religion. Indeed, Bertolini

15 For further references: Bazzoli, Giambattista Almici e la diffusione di Pufendorf, 46.

16 Michele Grandi, 'Avvertimento sopra questa traduzione italiana,' in Samuel Pufendorf, I doveri dell'uomo e del cittadino: tali che a lui dalla legge naturale sono prescritti, dalla versione francese di Giovanni Barbeyrac tradotti, e con molte aggiunte corretti ed illustrati da Michele Grandi accademico di Udine (Venezia: Francesco Pitteri, 1761), vol. I, XI-XII (author's translation).

17 Bazzoli, Giambattista Almici e la diffusione di Pufendorf, 46.

18 Sandro Landi, Il governo delle opinioni. Censura e formazione del consenso nella Toscana del Settecento (Bologna: Il Mulino, 2000), 254; Trampus, La traduzione toscana del Droit des gens di Emer de Vattel, 172. 
justified his decision to stop the printing by saying there were 'points too closely concerning royal rights.'19 There were two particularly delicate issues. The first was the contractualist theory of the state, the second the theory of 'limited' monarchy, which Burlamaqui and de Felice elaborated with reference to the model of the British 'constitutional monarchy' ${ }^{20}$ At all events, the censorship was temporary, and Bindi published the translation in 1780-1782. This sudden change of heart was very probably dictated by the broader view on the freedom of the press taken by the government. ${ }^{21}$

In Venice, Giovanni Gatti published in 1780 a translation of Burlamaqui's Principes du droit naturel. The translator was Count Benedetto Crispi, who signed the work with his initials, B.C. He wrote in his introduction that it was 'well known how passionately the more cultivated Nations of Europe have turned to the study of Natural Law, since Grotius systematized it', and that 'among these Italy has distinguished itself not a little, not only with new editions, translations, confutations of Grotius, of Hobbes, of Pufendorf and of Wolff, but also with original works by its expert and most profound authors.22 After listing the various European translations of Burlamaqui's treatise in England, Holland and Denmark, he pointed out that he had decided to translate the first edition of Burlamaqui's work (1747) instead of the later version annotated by de Felice because the latter obscured Burlamaqui's thinking.

Crispi also translated Burlamaqui's Principes du droit politique (1751). The work was published in the same year (1780), again by Gatti. Crispi was an aristocrat, famous for his excellent translations from German, English and, above all, French. Apart from Burlamaqui's works, he also translated Gabriel Bonnot de Mably's treatise on the public law of Europe, Il diritto pubblico dell'Europa, which was also published by Gatti, in 1784. The Count was a friend and protector of a group of Jesuits who, having been expelled from Spain in 1767 , had taken refuge in northern Italy. Crispi had no hesitation in involving them in his cultural and

\footnotetext{
19 Landi, Il governo delle opinioni, 255.

20 Ibid.

21 Ibid.

22 'abbastanza noto, con quanto ardore fiensi rivolte le più colte Nazioni d'Europa allo studio della giurisprudenza Naturale, da che Grozio lo ridusse a sistema [...] Tra queste si è pure distinta non poco l'Italia, non solo colle ristampe, traduzioni, confutazioni [del] Grozio, dell'Obbes, del Pufendorf e del Wolff, ma eziandio colle opere originali dei suoi più dotti, e più profondi scrittori' (author's translation). Conte Benedetto Crispi, 'Il traduttore a chi legge', in Jean-Jacques Burlamaqui, Principii del diritto naturale di G.G. Burlamachi consigliere di Stato, già professore di diritto naturale e civile in Ginevra (Venezia: Giovanni Gatti, 1780), vol. I, III-IV.
} 
editorial exploits. ${ }^{23}$ Indeed, to the translations of Burlamaqui's treatises were added notes by a former Jesuit, the Catalan Luciano Galissà y Costa, a specialist in oriental languages and, from 1782, prefect of the library of Ferrara. It has rightly been noted that the aim of Gallissà and Crispi was not merely to present these Protestant texts without offence to the Catholic Church, but actively to contribute to the circulation and diffusion of Burlamaqui's theories. ${ }^{24}$

In his Avvertimento of the translation of Burlamaqui's Principes du droit naturel, the publisher, Gatti, announced an Italian translation of Vattel's treatise on the law of nations. This translation had been done by Lodovico Antonio Loschi, ${ }^{25}$ under the title Il diritto delle genti, ovvero principii del diritto naturale applicati alla condotta e agli affari delle nazioni e de' sovrani, in three octavo volumes, republished in $1804-1805 .{ }^{26}$ It was based on the edition published in Neuchâtel in 1773 and edited by Frédéric Samuel Ostervald.

The Italian edition of Vattel's treatise, as Antonio Trampus points out, had two distinguishing features: respect for the author's intentions and enhancement by the translator's notes. ${ }^{27}$ Indeed, Loschi did not merely translate the text, but inserted some explanatory notes, particularly in the first volume.

23 Niccolò Guasti, L'esilio italiano dei gesuiti spagnoli. Identità, controllo sociale e pratiche culturali (1767-1798) (Roma: Edizioni di storia e letteratura, 2006), 282 and note 75 . Guasti underlines that for Crispi there is extensive archival documentation and correspondence. The Count was an interesting figure who shared ideas and cultural interests with the Jesuit emigrants who brought the ideas of the Spanish ilustración with them to Italy. See also Trampus, Il ruolo del traduttore nel tardo illuminismo, 95. For the Italian translation of Mably's work see Giuseppe Roggerone, L'abbé de Mably: politico della teologia illuminata (Firenze: Centro Editoriale Toscano, 1991), 179.

24 Francesco Berti, 'Illuminismo, rivoluzione, modernità: lo spirito del secolo in alcuni significativi scritti dei gesuiti espulsi,' in La presenza in Italia dei gesuiti iberici espulsi. Aspetti religiosi, politici, culturali, ed. Ugo Baldini and Gian Paolo Brizzi (Bologna: CLUEB, 2010), 330.

25 Lodovico Antonio Loschi (1744-1811) was a scholar and translator who lectured on ethics at the University of Modena; he had a minor role in the political life of Napoleon's 'Three-Year Republic' in northern Italy and in Napoleon's Kingdom of Italy: Trampus, Il ruolo del traduttore nel tardo illuminismo, 81-108.

26 Trampus illustrates the stages of publication of the work, noting in particular that the licences obtained for printing seem to have been acquired in a short time, that is, between 1780 and 1781 . The manuscript of the first volume was given permission to be printed on 22 March 1781, falsely indicating Lyon as the base for the typographer Giovanni Gatti, according to the judgement of the reviewer, Gasparo Gozzi; the second volume, later subdivided into two books, was granted permission on 22 September 1781 , on the basis of the favourable judgement of the reviewer, Cosimo Mei; see Il ruolo del traduttore nel tardo illuminismo, 92. The 1804-1805 edition appeared in three volumes, without any additions or modifications to the previous one.

On Loschi's notes see Trampus, Il ruolo del traduttore nel tardo illuminismo, 89. 
Loschi's notes, Trampus highlights, essentially concern comments or criticisms of the most obviously anti-clerical positions Vattel defended, for example by advocating freedom of religion and freedom of conscience as inviolable human rights. The translator also made various notes about personal liberties. For example, when Vattel describes the duties of the nation regarding its obligation to construct and maintain public works, as commanded by the sovereign, Loschi pointed out in his notes that these works must be proportionate to the interest and profit of the nation. ${ }^{28}$ It should be noted that the notes made by Loschi are, in any case, identifiable and do not distort the original text. In the Avvertimento, the translator specifically states: 'a translation can only be as beautiful and elegant as its original. It is quite sufficient that the work is recognized as excellent for its method and substance.'29

In the appendix to Il diritto delle genti Loschi included a translation of the entry 'Droit de la Nature, ou Droit naturel' written by Antoine-Gaspard Boucher d'Argis for the Encyclopédie of Diderot and d'Alembert. This seemed important to him as it showed 'in what condition this very noble and very useful science was found, when our author began to study it'. ${ }^{30}$ Boucher d'Argis explained that natural law was the 'science of morals' (science des moeurs, qu'on appelle 'morale'), which comprises certain rules of justice and equity, established by human reason among all men. He also stressed that the law of nature should not be confounded with the law of nations, for the latter comprises, in addition to the rules established by right reason, customs that may conflict with the natural order. Boucher d'Argis then provided a short historical overview in which, starting from Roman times, he mentions the works of the most famous jusnaturalists, first and foremost Grotius's De jure belli ac pacis, and then those of Pufendorf and Burlamaqui, but without entering into philosophical, let alone juridical, considerations. The content and structure of this encyclopaedia entry provoked a great deal of criticism, and the debate as to why Diderot wrote another entry, 'Droit naturel (Morale)', for insertion in his Encyclopédie immediately following that of Boucher d'Argis, is still going on. ${ }^{31}$

28 See Trampus, Il ruolo del traduttore nel tardo illuminismo, 100-101.

29 'una traduzione esser non può bella ed elegante che a misura del suo originale. Basta bene che l'opera sia riconosciuta eccellente per metodo e per la sostanza delle cose' (author's translation). Lodovico Antonio Loschi, 'Avvertimento del volgarizzatore,' in Emer de Vattel, Il diritto delle genti, ovvero principii del diritto naturale applicati alla condotta e agli affari delle nazioni e de' sovrani (Lyon: 1781), vol. I, vi.

30 Ibid.: 'in quale stato [si] ritrovasse questa nobilissima ed utilissima scienza, quando prese a trattarla il nostro autore' (author's translation).

31 Luigi Luporini, 'Per una lettura della voce "Droit naturel" nell'Encyclopédie,' Studi Storici, 28, 3 (1987): 679-697; Peter Schröder, 'Natural Law and Enlightenment in France and 
This brief review of Boucher d'Argis's entry on natural law is essential for understanding the climate in which the Italian translation of Vattel's treatise was published. Loschi felt compelled to distance himself from what might be dubbed an 'incomplete' encyclopaedia entry on natural law, and in response to offer the broad, well-conceived treatise of Vattel, which was considered by the translator the most accurate work on the law of nature and nations available at the time.

Loschi's translation had an adverse fate in the Kingdom of Naples during the French Revolution, being placed on the list of prohibited books. At the time, the revision of publications was carried out by Francesco Conforti, professor of the history of Catholic Councils at Naples University and theologian at the Neapolitan court, responsible for controlling the influx of foreign books. ${ }^{32}$ Conforti judged Vattel's Le droit des gens to be 'seditious, because it recognizes the right of the People to reform the constitution and change the government', but he especially railed against Loschi, because in his translation the kept the same maxims as were given in the original., ${ }^{33}$

Loschi's was the only Italian translation of Vattel's work printed in the eighteenth century, but the treatise had been circulating since the time of its first edition in 1758 and, thanks to later editions, certainly aroused great interest in many parts of the Italian peninsula because of its contributions to a wide range of subjects, from academic jurisprudence through applied legal doctrine to diplomacy. There are frequent references, for example, in Cesare Beccaria's Dei delitti e delle pene to Vattel's work, which 'together with that of Burlamaqui seems to constitute one of the main sources for the elaboration of the essay'. ${ }^{34}$ Significantly, Alessandro Verri, in 'Di alcuni sistemi di diritto pubblico' published in the journal Il Caffè (vol. I, 1764-65), states that Vattel was the only

Scotland - A Comparative Perspective,' in Early Modern Natural Law Theories: Contexts and Strategies in the Early Enlightenment, ed. T.J. Hochstrasser and Peter Schröder (Dordrecht: Kluwer, 2003), 297-317.

32 See Pasquale Villani, Mezzogiorno tra riforme e rivoluzione (Bari: Laterza, 1962), and Anna Maria Rao, 'La stampa francese a Napoli negli anni della Rivoluzione,' Mélanges de l'École française de Rome. Italie et Méditerranée, 102, 2 (1990): 478.

'sediziosa, perchè riconosce nel Popolo il diritto di riformare la costituzione e di cambiare il governo [...] si sono conservate le stesse massime, che si dettano nell'originale' (author's translation). Villani, Contributo alla storia dell'anticurialismo napoletano, 249.

34 'assieme a quella di Burlamaqui sembra costituire una delle fonti principali per l'elaborazione del saggio' (author's translation). Gianni Francioni, 'Nota al testo,' Cesare Beccaria, Dei delitti e delle pene, edizioni italiane del "Dei delitti e delle pene", ed. Luigi Firpo (Milano: Einaudi, 1984), 334. See also: Trampus, Il ruolo del traduttore nel tardo illuminismo, 83 . 
person 'who had grasped the truth [of public law] and was the one to peel away the illusions and misunderstandings from this science, reducing it to a system of ideas, not of words.'.35

The illustrious jurist Alberto de Simoni, too, fascinated by the theories of the école romande, attempted to translate Burlamaqui and considered Vattel to be 'l'umanissimo'. He made frequent reference to Vattel's theories in his Del furto e sua pena of 1776 and on more than one occasion had no hesitation in calling them 'absolutely right', ${ }^{36}$ an opinion shared by the jurist Paolo Risi. $^{37}$

In a totally different geographical, political and social context, the Droit des gens was widely consulted for the defence of the Bishop of Mileto, Giuseppe Maria Carafa. In Difesa del vescovo di Mileto e del Collegio dei Greci in Roma (1769), the bishop defended the Church's ownership and rights over the Abbey of Trinità of Mileto, which was being claimed by the court of Naples. The question was very complicated and of long standing, but the crux of his main thesis, overruled by the Court, was the correct interpretation of the Concordat of 2 June 1741 between the King of Naples, Charles of Bourbon, and Pope Benedict IV. Carafa argued that the Concordat ought to be interpreted according to Vattel's rules, which were called upon in their entirety by the bishop in defence of the Church's ownership of the Abbey. ${ }^{38}$

35 'abbia colta la verità [del diritto pubblico] e sia quello che abbia spogliata questa scienza dalle chimere e dagli equivoci riducendola a sistema di idee, non di parole' (author's translation). 'Discorso IX: Di alcuni sistemi del diritto pubblico' appeared, together with other writings of Alessandro Verri, in the journal Il Caffè and also published in Alessandro Verri, Discorsi vari del conte Alessandro Verri pubblicati nel giornale letterario intitolato Il Caffè (Milano: Silvestri, 1818), 349-375, here particularly 370.

36 Alberto De Simoni, Del furto e sua pena (Lugano: Agnelli, 1776), 13. De Simoni referred to book 1, chap. 13, § 171 of Le droit des gens, where Vattel deals with the degree of punishment and criticized the practice of punishing simple robbery with death. See Renato Pasta, 'Dei delitti e delle pene et sa fortune italienne: milieux juridiques et lecture "philosophique"', in Beccaria et la culture juridique des Lumières, (Actes du colloque européenne de Genève 25-26 Novembre 1995), ed. Michel Porret (Genève: Droz, 1997), 132; Italo Birocchi, 'De Simoni Alberto,' in Dizionario biografico dei giuristi italiani (XII-XX secolo), ed. Italo Birocchi et al. (Bologna: Il Mulino, 2013), vol. I, 718-720.

37 See Stefano Solimano, 'Paolo Risi e il processo penale (1766),' in Studi di storia del diritto (Milano: Giuffrè, 2001), vol. III, 440, note 59. About Risi: Stefano Solimano, 'Risi Paolo,' Dizionario Biografico Giuristi Italiani (XII-XX secolo), ed. Italo Birocchi, et al. (Bologna: Il Mulino, 2013), vol. II, 1694-1696.

38 Giuseppe Maria Carafa, Difesa del vescovo di Mileto e del Collegio dei Greci in Roma contro un'istanza fiscale ed una scrittura stampata col titolo di Dimostrazione del padronato della Real Corona, sulla chiesa e badia della Trinità di Mileto (Napoli: 1769), Xxxv-XL. 
From the very beginning, the reception of Vattel's work in Italy was probably linked to the great ability of the author to summarize and systematize natural law theory in a way which could prove particularly useful to Italian political culture, once it was detached from Vattel's critical approach to the Catholic Church. The specific features of Vattel's text, and its considerable conceptual and lexical modernization in particular, effectively led to new interpretations in the light of the political changes that had been triggered by the crisis of the ancien régime and by the Seven Years' War. Le droit des gens portrayed natural law as a 'science', capable of conceptualizing the shift from the analysis of mankind in the state of nature to the study of individuals as members of a political society. 39

In any case, the act of translating became a specific choice, deliberately aimed at meeting the need to 'recreate' Vattel's doctrine in the context of eighteenth-century Italy. Indeed, Vattel's work was not classified merely as a text on the law of nations. On the contrary, it was a sort of political guide to foreign affairs for the small states that at the time made up the Italian peninsula. ${ }^{40}$ Legal transfer, understood as a process of cultural translation, could be achieved if the very contents and aims of a work were able to adapt and mould themselves or - even better - to be re-read according to different historical and geographical requirements. ${ }^{41}$ As will be shown below, it was, for example, of particular interest in the Italian context that Vattel held the creation of a constitution, seen as a fundamental regulation, to be legitimate within a state, on condition that it pursued the common good of the citizens and was not imposed by outside interference. Having dealt with the essential features of the nation-state, he broadens his investigation to the state as an entity able to communicate on an international level. ${ }^{42}$ As Trampus observes, Vattel's treatise 'represents [...] a typical example of reproducing a cultural model outside of its original historical and geographical context, and adapted again and again, with interference from another culture, in new political and social areas.' ${ }^{43}$

39 Trampus, La traduzione toscana del Droit des gens di Emer de Vattel, 153-154.

40 Ibid.

41 See: Lena Foljanty, 'Legal Transfers as Processes of Cultural Translation: on the Consequences of a Metaphor,' Max Planck Institute for European Research Paper series 9 (2015): 7 , accessed 28 January 2017 , http://ssrn.com/abstract $=2682465$.

42 Trampus, La traduzione toscana del Droit des gens di Emer de Vattel, 153-154.

43 Ibid.: 'rappresenta [...] un caso tipico di riproduzione di un modello culturale al di fuori dell'originario contesto storico e geografico e adattato sempre più spesso, subendo l'interferenza di cultura terza, in nuovi ambiti politici e sociali' (author's translation). 


\section{Third Scenario: Translating Barbeyrac's, Burlamaqui's and Vattel's Ideas for Academic and Practical Purposes}

The Italian peninsula was of prime geostrategic importance during the eighteenth century, and this promoted the adoption and circulation of modern doctrines on the law of nations. Italy's universities continued the tradition of the jus commune and harboured a distinct style of Enlightenment thought, and the new law of nations was received in this general context. Only in the second half of the eighteenth century were chairs of natural law and law of nations established in various Italian states, almost always in those which were politically or culturally dependent on Austria. In many cases the teaching of natural law was linked to courses in public law, public universal law and the law of nations. ${ }^{44}$

It is interesting to note that works pertaining to the école romande, in particular Vattel's treatise on the law of nations, influenced academic teaching when chairs of natural law were established as a result of university reforms carried out at different periods. At the University of Pavia the works of Burlamaqui, Barbeyrac and Vattel on natural law were particularly valued. This can be seen from indirect references to their works in Institutiones juris naturalis and Institutiones juris publici universalis ${ }^{45}$ by Jean Baptiste Noël de Saint Clair, professor of natural and universal public law, as well as from other references in the teaching and writings of Abbot Pietro Tamburini. ${ }^{46}$

44 Among many see Giorgio Zordan, 'L'insegnamento del diritto naturale nell'Ateneo Patavino e i suoi titolari (1764-1855), Rivista di Storia del Diritto Italiano 72 (1999): 5-76. Gigliola di Renzo Villata, 'Le droit public en Lombardie au XVIIIe siècle et l'Europe,' in Science politique et droit public dans les facultés de droit européennes (XIIIe-XVIIIe siècle), ed. Jacques Krynen and Michael Stolleis (Frankfurt am Main: Klostermann, 2008), 583-612. For the references to Vattel within the Allegationes see Gigliola di Renzo Villata, 'Introduzione. La formazione del giurista in Italia e l'influenza culturale europea tra Sette e Ottocento: il caso della Lombardia,' in Formare il giurista. Esperienze nell'area lombarda tra Sette e Ottocento, ed. Gigliola di Renzo Villata (Milano: Giuffrè, 2004), 64 .

46 Pietro Stella, 'Pietro Tamburini nel quadro del giansenismo italiano,' in Atti del Convegno internazionale in occasione del $25^{\circ}$ della nascita (Brescia, 25-26 maggio 1989), ed. Paolo Corsini and Daniele Montanari (Brescia: Morcelliana, 1993), 193. About Tamburini see also: Paola Vismara, 'Pietro Tamburini e il "dispotismo pontificio", in Il giansenismo e l'Università diPavia. Studi in ricordo diPietro Stella, ed. Simona Negruzzo (Milano: Giuffrè, 2012), 95-114; Dale K. Van Kley, 'From the Catholic Enlightenment to the Risorgimento: the Exchange Between Nicola Spedalieri and Pietro Tamburini, 1791-1797,' Past \& Present 224, 1 (2014): 109-162; Alberto Carrera, Pietro Tamburini 'Giurista'. Per una storia della cultura giuridica giansenista italiana (PhD diss., University of Milan, 2015). 
Vattel particularly attracted scholars because he relied on Christian Wolff, whose thinking was often praised in academic circles. In Padua, for example, Abbot Matteo Franzoja was teaching natural law in 1773 using Wolff's Institutiones juris naturae et gentium as his textbook. In Pisa, Giovanni Maria Lampredi heavily relied on Vattel. ${ }^{47}$ Indeed, in his Iuris publici universalis, sive Iuris naturae et gentium theoremata, begun in 1767 , there are countless direct and indirect references to Vattel's theories. ${ }^{48}$ In the third part of that work, entirely devoted to jus gentium, Lampredi addresses the complex relationship between natural law and the law of nations, with reference to the most important exponents of natural jurisprudence. He rejects Wolff's proposal to found the law of nations on the idea of a civitas maxima, and accepts the positions defended, for example, by Barbeyrac and Heineccius. ${ }^{49}$ It seems however that Vattel's Le droit des gens were 'one of the works most used by the Tuscan jurist in the field of law of nations.' ${ }^{50}$

In 1788, Lampredi published his Del commercio dei popoli neutrali in tempo di guerra ${ }^{51}$ in which he fervently supported freedom of trade between neutral states - based on the law of nations and of treaty law - in response to the theses advanced by Ferdinando Galiani. ${ }^{52}$ This example provides insight into the way in which Vattel's theory of the law of nations was used in a debate regarding the practical diplomatic issue of neutrality. In 1782, Galiani had published his De' doveri e de' principi neutrali verso i guerreggianti e di questi verso i principi neutrali, a work that was well received throughout Europe and which 'might well be the crowning of his career as political author'.53 He was

47 Maria Rosa Di Simone, 'Linfluenza di Christian Wolff sul giusnaturalismo dell'area asburgica e italiana,' in Dal "De Jure Naturae et gentium" di Samuel Pufendorf alla codifcazione prussiana del 1794. Atti del convegno internazionale, Padova, 25-26 ottobre 2001, ed. Marta Ferronato (Padova: Cedam, 2005), 221-268, particularly 254; Maria Rosa Di Simone, 'Stato e diritto nel pensiero di Gian Rinaldo Carli,' in Percorsi del diritto tra Austria e Italia (secoli XVII-XX) (Milano: Giuffrè, 20o6), 139.

48 Paolo Comanducci,IlSettecento conservatore:Lampredieil dirittonaturale (Milano:Giuffrè, $1981), 267$.

49 Ibid., $262-264$.

50 Ibid., 269: 'è una delle opere più utilizzate dal giurista toscano in tema di diritto delle genti' (author's translation).

51 Concerning Lampredi for a reconstruction of the thought, the context and the doctrinal influences: Comanducci, Il Settecento conservatore; Fabrizio Vannini, 'Lampredi Giovanni Maria,' in Dizionario Biografico degli Italiani 63 (2004): 259-262. Concerning Lampredi, as professor of public law in Pisa, see Giuliano Marini, 'Dal diritto naturale alla filosofia del diritto', in Storia dell'Università di Pisa (Pisa: Pacini, 200o), vol. II, 635-661.

52 Paolo Comanducci, 'Lampredi Maria Giovanni,' Dizionario Biografico Giuristi Italiani (XIIXX secolo), ed. Italo Birocchi et al. (Bologna: Il Mulino, 2013), vol. I, 1138-1141.

53 'ben potrebbe essere il coronamento della sua carriera di scrittore politico' (author's translation). Koen Stapelbroek, 'I significati della neutralità: la storia del commercio 
very critical of the position taken by Vattel regarding the neutral states and particularly challenged the neutral party's freedom of trade that preceded the distinction between active and passive trade. He rails against the lack of explanations given by Vattel: 'Arguments or reasons in support of his sentiment he gives none, and perhaps he had none in his head. The example of the Swiss nation and of others in Europe were all his proof. ${ }^{54}$ Galiani describes Vattel's doctrine of neutrality as 'bizarre', because 'he - [Vattel] - himself applauds it as a more humane teaching, and capable of diminishing the calamities of Europe, by extinguishing the sparks of new wars'. He also observes ironically that Vattel 'in his preface announced a book on the Law of Nations and not a work of Political Dissimulation, or Christian Patience.'.55

Lampredi, in turn, uses Le droit des gens as his main source for contesting Galiani's position. The introduction to Del commercio dei popoli neutrali in tempo di guerra comprises a detailed examination of the principles regulating trade between neutral states and of the most significant doctrinal positions throughout history. Lampredi has no doubt that the most important was that of Alberico Gentili, who endeavoured to create 'a system of justice even amidst the clamour of war, 56 and whose ideas had 'to some extent paved the way for

mediterraneo in Dei Doveri dei Principi Neutrali,' in Il linguaggio del tardo illuminismo. Politica, diritto e società civile, ed. Antonio Trampus (Roma: Edizioni di storia e letteratura, 2011), 77. See also Koen Stapelbroek, Love, Self-deceit and Money: Commerce and Morality in the Early Neapolitan Enlightenment (Toronto: University of Toronto Press, 2008).

54 'Argomenti o ragioni da stabilire il suo sentimento non ne dà, e forse non ne aveva nel suo capo. L'esempio della nazione Svizzera e di altre in Europa formano tutta la sua prova' (author's translation). Ferdinando Galiani, De' doveri e de' principi neutrali verso i guerreggianti e di questi verso i principi neutrali (Napoli: 1782), 120. Galiani intensifies his critique ibid., 120-121, note 2 , where he stresses that giving reasons is all the more important when writing about the law of nations, for states cannot refer to any other laws than the treaties voluntarily stipulated by them.

55 Ibid., 123: 'se n'applaudisce egli stesso come d'un insegnamento più umano, e capace di diminuire le calamità dell'Europa, coll'estinguere le scintille di nuove guerre [...]' (author's translation). Ibid., 124: 'Egli aveva nel suo frontespizio annunziato un libro del Diritto delle genti e non una opera della Dissimulazione Politica, o della Pazienza Cristiana' (author's translation). In endeavouring to find an explanation for Vattel's theory, Galiani declares ibid., 124, note 2, that he wrote his Droit des gens with the intention to please the generous court of Saxony and the Swiss cantons, but, living there, it 'is less excusable that he did not realize that their ancient usage of giving troops to the Sovereigns of Europe has nothing to do with his question' (author's translation).

$5^{6}$ 'un sistema di giustizia anche tra lo strepito dell'armi' (author's translation). Maria Giovanni Lampredi, Del commercio dei popoli neutrali in tempo di guerra (Firenze: 1788), 4. See Enrico Spagnesi, 'The trade of "neutral nations" as viewed by the publicist Lampredi,' in War, Trade and Neutrality. Europe and the Mediterranean in seventeenth and eighteenth centuries, ed. Antonella Alimento (Milano: FrancoAngeli 2011), 233-246. 
the famous Hugo Grotius who, writing with greater elegance, and adorning his Treatise with polished [...] erudition, practically banished his Master from memory, though he almost entirely followed his own design'. ${ }^{57}$ As Lampredi sees it, Gentili focuses on the problem of trade for neutral nations 'as an aside, and says just enough to conclude that $[. .$.$] it is difficult to disentangle as it$ seems [...] that the arguments of the warmonger, who blocks and forbids the trade of the neutrals, and the arguments of the neutrals, who say they are offended by this embargo, are both founded in reason. ${ }^{\prime 8}$ The question was, as he wrote, still pending and unresolved, despite the fact that almost two hundred years had passed since the publication of Gentili's De jure belli libritres. For this reason he intended to address the question, while giving great consideration to the context in which he lived, the customs of the nations and the reasons that were the cause of confusion in the treatment of trade. Attention to practice and to the historical and political situation was also a characteristic of Vattel's work, to which Lampredi referred. He cites Vattel, as an author better able to give prominence to the law of nations than Wolff. Somewhat confusing Vattel's role, Lampredi maintained that he spoke more clearly than Wolff when he translated the latter into French and thereby 'removed his abominably scholastic air and adorned him with much less heavy robes' 59

Finally, as far as Giovanni Gatti's translation of Burlamaqui's Principes du droit naturel is concerned, it was especially well received in Italy, particularly in academic circles. In 1812, Pietro Antonio Magalotti, professor of natural law in Perugia, was still making great use of Burlamaqui. According to Vittor Ivo Comparato, it was 'a model of synthesis that did not separate the natural law of Grotius from the utilitarianism of Pufendorf and allowed Magalotti to take that middle way which time suggested. ${ }^{60}$ In the first part of his lectures, Magalotti actually

57 Lampredi, Del commercio dei popoli neutrali in tempo diguerra, 6: 'in certo modo la strada al celebre Hugo Grotius, il quale scrivendo con maggiore eleganza, ed ornando il suo Trattato di forbita [...] erudizione fece quasi scordare il suo Maestro, di cui però seguitò quasi totalmente il disegno' (author's translation).

$5^{8}$ Ibid., 5: 'per incidenza, e dice quanto basta per concludere che [...] è difficile da sciogliersi sembrando, dic'egli, che tanto il Belligerante, che impedisce e vieta il commercio dei Neutrali, quanto ai Neutrali, che si chiamano offesi da questo impedimento siano fondati in ragione' (author's translation).

59 Ibid., 65: 'ma più chiaramente di lui ha parlato il suo redattore, che traducendolo in lingua francese gli ha tolto la disgustevole aria scolastica, e l'ha ornato di vesti assai più leggiadre' (author's translation).

6o 'un modello di sintesi che non separava il giusnaturalismo groziano dall'utilitarismo pufendorfiano e consentiva al Magalotti di percorrere quella via di mezzo che i tempi 
follows the order and titles of Burlamaqui's chapters and paragraphs, copying them word for word, almost as if he had adopted the work as a textbook. He then broadens his sources in the second part, and distances himself from Burlamaqui, disputing with him, for example, the delicate question of whether reason was sufficient as a foundation for moral obligation, independent of the will of God. ${ }^{61}$

\section{$5 \quad$ Conclusion}

This chapter has presented an overview of the research on the reception of Barbeyrac's, Burlamaqui's and Vattel's works in the Italian context, with a focus on translation. Translation, of course, is not a passive phenomenon, and the end product can reshape the text itself. It is impossible to talk about simple copies or works that have very little originality, because in the context in which they are used, as in the case of translations of Barbeyrac, Vattel or Burlamaqui, they are creative in their own right and, at the same time, they generate cultural and political identity.

In the first scenario, the Italian translation of Barbeyrac's French version of Pufendorf's work highlights the role of the translator as a legal, cultural and social mediator. Almici translates and, at the same time, reflects on the positions of Barbeyrac and Pufendorf, also making use of newly published contemporary works, such as Vattel's Le droit des gens. In the second scenario, it is shown how, in other Italian contexts, translations of Burlamaqui and Vattel were vehicles for political reflection and influenced legal practice. In the third scenario, translation is discussed in its broadest sense as an instrument for doctrinal and academic assimilation of the theories of natural law and law of nations, contributing to the creation of a separate subject that would become international law over the nineteenth century.

It has thus been shown that in addition to the famous works on natural law and the law of nations in the tradition of scholastic philosophy and moral theology, there was in eighteenth-century Italy a growing interest in books that aimed to spread the ideas of the école romande du droit naturel. This trend aided the advent of newer and more open-minded theories on natural law and the law of nations, which was integral to the Enlightenment understood as a continuous process of change. ${ }^{62}$ There was, therefore, a clear 'common desire'

suggerivano' (author's translation). Vittor Ivo Comparato, 'Il diritto di natura a Perugia tra la Repubblica romana e l'Unità,' Annali di storia delle università italiane 18 (2014): 221-242. 61 Ibid.

62 Bazzoli, Giambattista Almici e la diffusione di Pufendorf, 100. 
across eighteenth-century Italy to make use of Le droit des gens and texts of the école romande in adapting natural law and the law of nations at a variety of legislative, political and academic levels.

\section{Bibliography}

Bandelier, André, Emer de Vattel à Jean Henry Samuel Formey. Correspondance autour $d u$ Droit des gens (Paris: Editions Honoré Champion, 2012), 103-105.

Bazzoli, Maurizio, 'Aspetti della recezione di Pufendorf nel Settecento italiano,' in Dal 'De Jure Naturae et gentium' di Samuel Pufendorf alla codificazione prussiana del 1794. Atti del convegno internazionale, Padova, 25-26 ottobre 20o1, ed. Marta Ferronato (Padova: Cedam, 2005), 41-6o.

Bazzoli, Maurizio, 'Giambattista Almici e la diffusione di Pufendorf nel Settecento Italiano,' Critica Storica 16 (1979): 3-10o.

Beccaria, Cesare, Dei delitti e delle pene, Le edizioni italiane del "Dei delitti e delle pene", ed. Luigi Firpo (Milano: Einaudi, 1984).

Berti, Francesco Illuminismo, rivoluzione, modernità: lo spirito del secolo in alcuni significativi scritti dei gesuiti espulsi, in La presenza in Italia dei gesuiti iberici espulsi. Aspetti religiosi, politici, culturali, ed. Ugo Baldini, Gian Paolo Brizzi (Bologna: ClueB, 2O10), 321-336.

Birocchi, Italo et al. (ed.), Dizionario Biografico Giuristi Italiani (XII-XX secolo) (Bologna: Il Mulino, 2013).

Buonafede, Appiano, Della restaurazione di ogni filosofia pe' secoli XVI, XVII, XVIII (Milano, Venezia: Pasquali, 1792).

Burlamaqui, Jean Jacques, Principii del diritto naturale di G.G. Burlamachi consigliere di Stato, già professore di diritto naturale e civile in Ginevra (Venezia: Giovanni Gatti, $1780)$.

Carafa, Giuseppe Maria, Difesa del vescovo di Mileto e del Collegio dei Greci in Roma contro un'istanza fiscale ed una scrittura stampata col titolo di Dimostrazione del padronato della Real Corona, sulla chiesa e badia della Trinità di Mileto (Napoli: 1769).

Carrera, Alberto, Pietro Tamburini "Giurista". Per una storia della cultura giuridica giansenista italiana (PhD diss., University of Milan, 2015).

Comanducci, Paolo, Il Settecento conservatore: Lampredi e il diritto naturale (Milano: Giuffrè, 1981).

Comparato, Vittor Ivo, 'Il diritto di natura a Perugia tra la Repubblica romana e l'Unità,' Annali di storia delle università italiane, 18 (2014): 221-242.

Conti, Vittorio (ed.), La recezione di Grozio a Napoli nel Settecento (Firenze: Centro Editoriale Toscano, 2002).

De Simoni, Alberto, Del furto e sua pena (Lugano: Agnelli, 1776). 
Di Renzo Villata, Gigliola, 'Introduzione. La formazione del giurista in Italia e l'influenza culturale europea tra Sette e Ottocento: il caso della Lombardia,' in Formare il giurista. Esperienze nell'area lombarda tra Sette e Ottocento, ed. Gigliola di Renzo Villata (Milano: Giuffrè, 2004), 1-106.

Di Renzo Villata, Gigliola, 'Le droit public en Lombardie au XVIIIe siècle et l'Europe,' in Science politique et droit public dans les facultés de droit européennes (XIIIe-XVIIIe siècle), ed. Jacques Krynen, Michael Stolleis (Frankfurt am Main: Klostermann, 2008), 583-612.

Di Simone, Maria Rosa, 'L'influenza di Christian Wolff sul giusnaturalismo dell'area asburgica e italiana,' in Dal 'De Jure Naturae et gentium' di Samuel Pufendorf alla codificazione prussiana del 1794. Atti del convegno internazionale, Padova, 25-26 ottobre 2001, ed. Marta Ferronato (Padova: Cedam, 2005), 221-268.

Di Simone, Maria Rosa, 'Stato e diritto nel pensiero di Gian Rinaldo Carli,' in Percorsi del diritto tra Austria e Italia (secoli XVII-XX) (Milano: Giuffrè, 2006), 135-158.

Dufour, Alfred, 'Die Ecole romande du droit naturel - ihre deutschen Wurzeln,' in $\mathrm{Hu}$ manismus und Naturrecht in Brandenburg-Preußen, ed. Hans Thieme (Berlin: W. de Gruyter, 1979), 133-143.

Dufour, Alfred, Le mariage dans l'école allemande du droit naturel moderne au XVIIIe siècle (Paris: Libraire générale de droit et de jurisprudence, 1976).

Duve, Thomas, 'European Legal History - Global Perspectives Working Paper for the Colloquium European Normativity - Global Historical Perspectives (Max Planck Institute for European Legal History, September, 2nd-4th 2013),' Max Planck Institute for European Legal History Research Paper Series 6 (2013), accessed 28 January 2017, https://papers.ssrn.com/sol3/papers.cfm?abstract_id=2292666.

Ferrari, Stefano (ed.), Fortunato Bartolomeo De Felice. Un intellettuale cosmopolita nell'Europa dei Lumi (Milano: FrancoAngeli, 2017).

Fiocchi, Malaspina Elisabetta, L'eterno ritorno del Droit des gens di Emer de Vattel (secc. XVIII-XIX). L'impatto sulla cultura giuridica in prospettiva globale (Frankfurt am Main: Global Perspectives on Legal History, Max Planck Institute for European Legal History Open Access Publication, 2017), http://dx.doi.org/ $10.12946 /$ gplh8.

Foljanty, Lena, 'Legal Transfer as Processes of Cultural Translation: on the Consequences of a Metaphor,' Max Planck Institute for European Research Paper series 9 (2015), accessed 28 January 2017, http://ssrn.com/abstract=2682465.

Galiani, Ferdinando, De' doveri e de' principi neutrali verso i guerreggianti e di questi verso i principi neutrali (Napoli: 1782).

Guasti, Niccolò, L'esilio italiano dei gesuiti spagnoli. Identità, controllo sociale e pratiche culturali (1767-1798) (Roma: Edizioni di storia e letteratura, 2006).

Labriola, Giulia Maria, Barbeyrac interprete di Pufendorfe Grozio. Dalla costruzione della sovranità alla teoria della resistenza, (Napoli: Editoriale Scientifica, 2003). 
Lampredi, Maria Giovanni, Del commercio dei popoli neutrali in tempo di guerra (Firenze: 1788).

Landi, Sandro, Il governo delle opinioni. Censura e formazione del consenso nella Toscana del Settecento (Bologna: Il Mulino, 200o).

Luporini, Luigi, 'Per una lettura della voce "Droit naturel" nell'Encyclopédie,' Studi Storici 28/3 (1987): 679-697.

Marini, Giuliano, 'Dal diritto naturale alla filosofia del diritto,' in Storia dell'Università di Pisa (Pisa: Pacini, 200o), vol. II, 635-661.

Mili, Callimaco, 'Osservazioni critiche sul libro intitolato Dei delitti e delle pene,' Nuova raccolta d'opuscoli scientifici e filologici 13 (1765): II-XLVII.

Padoa, Schioppa Antonio, Storia del diritto in Europa. Dal medioevo all'età contemporanea (Bologna: Il Mulino, 2007).

Päivärinne, Meri, 'Translating Grotius's De jure belli ac pacis: Courtin vs Barbeyrac,' Translation Studies 5/1 (2012): 33-47.

Panizza, Diego, 'La traduzione italiana del "De iure naturae" di Pufendorf: giusnaturalismo moderno e cultura cattolica nel Settecento,' Studi Veneziani 11 (1969): 483-528.

Pasta, Renato, 'Dei delitti e delle pene et sa fortune italienne : milieux juridiques et lecture "philosophique"' in Beccaria et la culture juridique des Lumières, (Actes du colloque européen de Genève 25-26 Novembre 1995), ed. Michel Porret (Genève: Droz, 1997), 119-148.

Petronio, Giuseppe, L'autore e il pubblico (Pordenone: Studio Tesi, 1981).

Pufendorf, Samuel, Il diritto della natura e delle genti o sia sistema generale de' principii li più importanti di morale, giurisprudenza e politica, rettificato, accresciuto e illustrato (Venezia: Pietro Valvasense, 1757).

Pufendorf, Samuel, Il diritto della natura e delle genti o sia sistema generale de' principii li più importanti di morale, giurisprudenza e politica, rettificato, accresciuto e illustrato (Venezia: Pietro Valvasense, 1759).

Pufendorf, Samuel, I doveri dell'uomo e del cittadino: tali che a lui dalla legge naturale sono prescritti, dalla versione francese di Giovanni Barbeyrac tradotti, e con molte aggiunte corretti ed illustrati da Michele Grandi accademico di Udine (Venezia: Francesco Pitteri, 1761).

Quaglioni, Diego, 'Pufendorf in Italia. Appunti e notizie della prima diffusione della traduzione italiana del De iure naturae et gentium,' Il Pensiero Politico 32 (1999): 23-25o.

Rao, Anna Maria, 'La stampa francese a Napoli negli anni della Rivoluzione,' Mélanges de l'École française de Rome. Italie et Méditerranée, 102/2 (1990): 469-520.

Roggerone, Giuseppe, L'abbé de Mably: politico della teologia illuminata (Firenze: Centro Editoriale Toscano, 1991).

Sofri, Gianni, 'Almici Pietro Camillo,' in Dizionario Biografico degli Italiani 2 (1960), 512. Solimano, Stefano, 'Paolo Risi e il processo penale (1766),' in Studi di storia del diritto (Milano: Giuffrè, 2001), vol. III, 419-519. 
Spagnesi, Enrico, "The trade of "neutral nations" as viewed by the publicist Lampredi,' in War, Trade and Neutrality. Europe and the Mediterranean in seventeenth and eighteenth centuries, ed. Antonella Alimento (Milano: Franco Angeli, 2011), 233-246.

Stapelbroek, Koen, 'I significati della neutralità: la storia del commercio mediterraneo in Dei Doveri dei Principi Neutrali,' in Il linguaggio del tardo illuminismo. Politica, diritto e società civile, ed. Antonio Trampus (Roma: Edizioni di storia e letteratura, 2011), 53-79.

Stapelbroek, Koen, Love, Self-deceit and Money: Commerce and Morality in the Early Neapolitan Enlightenment (Toronto: University of Toronto Press, 2008).

Stella, Pietro, 'Pietro Tamburini nel quadro del giansenismo italiano,' in Atti del Convegno internazionale in occasione del $250^{\circ}$ della nascita (Brescia, 25-26 maggio 1989), ed. Paolo Corsini, Daniele Montanari (Brescia: Morcelliana, 1993).

Stoffella, Stefania, 'Assolutismo e diritto naturale in Italia nel Settecento', Annali dell'Istituto storico italo-germanico 26 (2000): 137-175.

Stoffella, Stefania, 'Il diritto di resistenza nel Settecento Italiano. Documenti per la storia della traduzione del De iure naturae et gentium di Pufendorf,' Magistrature et politique 2 (2001): 173-199, accessed 28 January 2017, http://laboratoireitalien .revues.org/261.

Trampus, Antonio, 'Il ruolo del traduttore nel tardo illuminismo: Lodovico Antonio Loschi e la versione italiana del Droit de gens di Emer de Vattel,' in Il linguaggio del tardo illuminismo. Politica, diritto e società civile, ed. Antonio Trampus (Roma: Edizioni di storia e letteratura, 2011), 81-108.

Trampus, Antonio, 'Dalla libertà religiosa allo Stato nazione: Utrecht e le origini del sistema internazionale di Emer de Vattel,' in I trattati di Utrecht: una pace di dimensione europea, ed. Frédéric Ieva (Roma: Viella, 2016), 93-106.

Trampus, Antonio, 'La traduzione toscana del Droit des gens di Emer de Vattel (circa 1780): contesti politici, transferts culturali e scelte traduttive,' in Traduzione e Transferts nel XVIII secolo tra Francia, Italia e Germania, ed. Giulia Cantarutti, Stefano Ferrari (Milano: FrancoAngeli, 2013), 153-174.

Trampus, Antonio, 'Le costituzioni italiane prime di Cadice: Vattel e le radici democratiche italiane,' in Cadice e oltre: costituzione, nazione e libertà. La carta gaditana nel bicentenario, ed. Fernando García Sanz et al. (Roma: Istituto per la Storia del Risorgimento italiano, 2015), 161-172.

Trampus, Antonio, 'The circulation of Vattel's Droit des gens in Italy: the doctrinal and practical model of government,' in War, Trade and Neutrality. Europe and the Mediterranean in seventeenth and eighteenth centuries, ed. Antonella Alimento (Milano: FrancoAngeli, 2011), 217-232.

Van Kley, Dale K., 'From the Catholic Enlightenment to the Risorgimento: the Exchange Between Nicola Spedalieri and Pietro Tamburini, 1791-1797,' Past \& Present 224/1 (2014): 109-162. 
Vannini, Fabrizio, 'Lampredi Giovanni Maria,' in Dizionario Biografico degli Italiani 63 (2004), 259-262.

Vattel, Emer de, The Law of Nations, Or, Principles of the Law of Nature, Applied to the Conduct and Affairs of Nations and Sovereigns, with Three Early Essays on the Origin and Nature of Natural Law and on Luxury, ed. Béla Kapossy, Richard Whatmore (Indianapolis, IN: Liberty Found, 2008).

Vattel, Emer de, Il diritto delle genti, ovvero principii del diritto naturale applicati alla condotta e agli affari delle nazioni e de' sovrani (Lyon: 1781).

Vec, Miloš, 'L'ambassade dans la science du droit des gens,' in Les écrits relatifs à l'ambassadeur et à l'art de négocier du Moyen Âge au début du XIX $X^{e}$ siècle, ed. Stefano Andretta, Stéphane Péquignot and Jean-Claude Waquet (Rome: École française de Rome, 2015), 487-522.

Verri, Alessandro, Discorsi vari del conte Alessandro Verri pubblicati nel giornale letterario intitolato Il Caffè (Milano: Silvestri, 1818).

Villani, Pasquale, Mezzogiorno tra riforme e rivoluzione (Bari: Laterza, 1962).

Vismara, Paola, 'Pietro Tamburini e il "dispotismo pontificio", in Il giansenismo e l'Università di Pavia. Studi in ricordo di Pietro Stella, ed. Simona Negruzzo (Milano: Giuffrè, 2012), 95-114.

Zordan, Giorgio, 'L'insegnamento del diritto naturale nell'Ateneo Patavino e i suoi titolari (1764-1855),' Rivista di Storia del Diritto Italiano 72 (1999): 5-76.

Zurbuchen, Simone, Das Prinzip des Naturrechts in der école romande du droit naturel,' in Jahrbuch für Recht und Ethik 12 (2004): 189-211.

Zurbuchen, Simone, 'Teaching the Law of Nature and Nations in the Swiss Context,' Etudes Lumières.Lausanne, 6 (novembre 2018): 1-19, accessed 15 February 2019, http://lumieres.unil.ch/fiches/biblio/9472/. 
Elisabetta Fiocchi Malaspina - 9789004384200 Downloaded from Brill.com04/26/2023 10:10: ๑9AM via free access 